University of Nebraska - Lincoln

DigitalCommons@University of Nebraska - Lincoln

USDA National Wildlife Research Center - Staff Publications
U.S. Department of Agriculture: Animal and Plant Health Inspection Service

July 2004

\title{
GnRH immunocontraception of male cats
}

Julie K. Levy

University of Florida

Lowell A. Miller

National Wildlife Research Center, United States Department of Agriculture

P. Cynda Crawford

University of Florida

Jerry W. Ritchey

Oklahoma State University, Stillwater, OK

Megan K. Ross

University of Florida

See next page for additional authors

Follow this and additional works at: https://digitalcommons.unl.edu/icwdm_usdanwrc

Part of the Environmental Sciences Commons

K. Levy, Julie; Miller, Lowell A.; Crawford, P. Cynda; Ritchey, Jerry W.; Ross, Megan K.; and Fagerstone, Kathleen A., "GnRH immunocontraception of male cats" (2004). USDA National Wildlife Research Center Staff Publications. 369.

https://digitalcommons.unl.edu/icwdm_usdanwrc/369

This Article is brought to you for free and open access by the U.S. Department of Agriculture: Animal and Plant Health Inspection Service at DigitalCommons@University of Nebraska - Lincoln. It has been accepted for inclusion in USDA National Wildlife Research Center - Staff Publications by an authorized administrator of DigitalCommons@University of Nebraska - Lincoln. 


\section{Authors}

Julie K. Levy, Lowell A. Miller, P. Cynda Crawford, Jerry W. Ritchey, Megan K. Ross, and Kathleen A. Fagerstone 


\title{
GnRH immunocontraception of male cats
}

\author{
Julie K. Levy ${ }^{\mathrm{a}, *}$, Lowell A. Miller ${ }^{\mathrm{b}}$, P. Cynda Crawford ${ }^{\mathrm{a}}$, \\ Jerry W. Ritchey ${ }^{\mathrm{c}}$, Megan K. Ross ${ }^{\mathrm{a}}$, \\ Kathleen A. Fagerstone ${ }^{\mathrm{b}}$ \\ ${ }^{\mathrm{a}}$ Department of Small Animal Clinical Sciences, College of Veterinary Medicine, \\ University of Florida, Gainesville, FL 32610, USA \\ ${ }^{\mathrm{b}}$ National Wildlife Research Center, United States Department of Agriculture, \\ Fort Collins, CO 80521, USA \\ ${ }^{\mathrm{c}}$ Department of Veterinary Pathobiology, College of Veterinary Medicine, \\ Oklahoma State University, Stillwater, OK 74078, USA
}

Received 18 November 2003; accepted 23 December 2003

\begin{abstract}
The development of nonsurgical contraceptives for cats may facilitate population control of the species. The purpose of this study was to investigate the utility of GnRH for immunocontraception of male cats. Male cats $(n=12)$ were divided into groups of three and were immunized once with 0 (sham), 50, 200, or $400 \mu \mathrm{g}$ synthetic GnRH coupled to keyhole limpet hemocyanin and combined with a mycobacterial adjuvant to enhance immunogenicity. GnRH antibody titer, serum testosterone concentration, and scrotal size were determined monthly. At 6 months, semen was collected by electroejaculation and testes were examined histologically. GnRH antibodies were detected in all cats receiving GnRH vaccine by 1 month post-treatment and persisted throughout the study. No dose effect of GnRH was observed; titers were not different among cats treated with 50,200 , or $400 \mu \mathrm{g}$ GnRH $(P=0.5)$. Six of nine treated cats were classified as responders based on high GnRH antibody titers $(>32,000)$. By 3 months post-treatment, responder cats had undetectable testosterone concentrations and testicular atrophy. Nonresponder cats had GnRH titers of 4000-32,000 and testosterone concentrations intermediate between responder and sham-treated cats. At 6 months, total sperm counts were similar for sham-treated cats $\left(3.1 \pm 1.8 \times 10^{6}\right.$ sperm) and nonresponder cats $\left(3.4 \pm 1.6 \times 10^{6}\right.$ sperm; $\left.P=0.7\right)$. Only one of the six responder cats produced sperm, none of which were motile. Combined testicular weights of responder cats $(1.3 \pm 0.1 \mathrm{~g})$ were lower than sham-treated controls $(5.3 \pm 1.3 \mathrm{~g} ; P=0.02)$ and nonresponder cats $(2.9 \pm 0.3 \mathrm{~g} ; P=0.02)$. Histologic evaluation of the testes revealed that in responder cats, the interstitial cells that were present were pale and shrunken compared to the plump, polyhedral eosinophilic cells in sham-treated cats. GnRH responder cats had marked
\end{abstract}

\footnotetext{
*Corresponding author. Tel.: +1-352-392-4700x5717; fax: +1-352-392-6125.

E-mail address: levyj@mail.vetmed.ufl.edu (J.K. Levy).
} 
tubular atrophy with vacuolated Sertoli cells and a paucity of germ cells. Single-dose GnRH treatment resulted in testosterone concentrations and semen quality consistent with immunocastration in a majority of cats treated.

(C) 2004 Elsevier Inc. All rights reserved.

Keywords: Cats; Immunocontraception; GnRH; Semen; Testosterone; Testicle

\section{Introduction}

The presence of large populations of feral cats leads to adverse impacts on cat welfare, public health, and the environment. Considerable controversy exists regarding optimal methods for controlling feral cats, including what is most practical, effective, and humane [1]. Recently, interest has turned to immunocontraception for nonlethal control of "pest" species [2-4]. An ideal feline immunocontraceptive would have a high margin of safety for treated animals and the environment, be effective in a high percentage of treated animals, have a rapid onset and long duration of activity following a single treatment, inhibit sex hormone production, be efficacious in all animals regardless of sex or age, and be simple to deliver in the field.

Immunization against GnRH may achieve many characteristics of an ideal immunocontraceptive [5]. GnRH is a decapeptide produced in the cat by telencephalic and diencephalic neurons and released from the median eminence into the capillary plexus of the hypothalamus [6]. Preovulatory release of $\mathrm{GnRH}$ follows somatosensory stimuli received during coitus in species such as cats in which females are induced rather than spontaneous ovulators [7]. Therefore, antibodies against hypothalamic GnRH prevent the normal cascade of hormone secretion that is required for gonadal regulation and gamete production [8]. GnRH is an ideal candidate for immunocontraception of stray animals, because a single product would be effective in both males and females [5-7]. Because the mechanism of action is the prevention of GnRH interaction with receptors on pituitary gonadotrope cells, all downstream hormonal activities would be inhibited. This has a distinct advantage over immunocontraceptive strategies that preserve hormone activity, because sex hormones contribute to undesirable nuisance behaviors such as fighting, marking, wandering, and calling, and to adverse health effects, including mammary neoplasia, pyometra, and prostatitis.

Effective long-term immunity classically requires a prime-boost series of immunizations, followed by additional boosting to maintain immunity throughout life. In most wildlife situations, repeated capture for booster vaccines is not feasible. Because stray cats, like other wild "pest" species, are likely to be caught only once, practicality dictates that an effective vaccine would be capable of delivering long-lasting immunity with a single treatment. GnRH, a decapeptide self-antigen, is a weak immunogen. To enhance antigenicity, multimers of a synthetic GnRH have been coupled to a large foreign protein, keyhole limpet hemocyanin (KLH), and combined with a mycobacterial adjuvant. This vaccine construct blocked hormone production and pregnancy in deer $[9,10]$ and wild rats [11] and has been reported to induce high GnRH antibodies in squirrels, pigs, rabbits, coyotes, horses, and bison following a single dose [12]. 
The purpose of this study was to investigate the utility of GnRH for immunocontraception of cats.

\section{Materials and methods}

\subsection{Cats}

Twelve 9- to 12-month-old specific-pathogen-free male domestic shorthair cats were acquired from a commercial vendor (Liberty Research, Liberty Corners, NJ, USA). The cats were housed in groups of three in the Animal Care Services facilities at the University of Florida College of Veterinary Medicine, which are accredited by the Association for Assessment and Accreditation of Laboratory Animal Care. Cat housing consisted of indoor runs with raised resting benches and was climate controlled to maintain ambient temperatures between 21 and $23{ }^{\circ} \mathrm{C}$ with a 14-h light:10-h dark cycle. Food and water were available at all times. The experimental design was approved by the Institutional Animal Care and Use Committee. All cats were surgically castrated and adopted to private homes at the conclusion of the study.

\subsection{Vaccine construction}

The GnRH-KLH vaccine construct was developed by the National Wildlife Research Center (NWRC) in Fort Collins, CO, USA. The 10-amino acid GnRH peptide hormone was made immunogenic by coupling the peptide to keyhole limpet hemocyanin (KLH; Pierce Endogen, Rockford, IL, USA). The GnRH used in this study was synthesized at Macromolecular Resources, Colorado State University (Fort Collins, CO, USA) with the structure [pEHWSYGLRPGGC-SH]. The underlined amino acids represent the native $\mathrm{GnRH}$ molecule. A glycine was added at the $\mathrm{C}$ terminus as a spacer and a cysteine was added to ensure consistent alignment of the peptide to the maleimide-activated protein carrier KLH. The aqueous-based GnRH-KLH conjugate was combined in a 1:1 ratio by volume with a novel adjuvant (AdjuVac ${ }^{\mathbb{R}}$ ), which is an oil-based modified USDA-licensed Johne's disease vaccine (Mycopar ${ }^{\circledR}$; Fort Dodge Animal Health, Fort Dodge, IA, USA) containing small quantities of killed $M$. avium. The GnRH/KLH/AdjuVac ${ }^{\circledR}$ vaccine has an APHIS/USDA patent-pending status.

\subsection{Treatment}

Cats were divided into four treatment groups of three cats each. The sham group received vaccines containing all components except GnRH-KLH. Three treatment groups received vaccines containing 50, 200, or $400 \mu \mathrm{g} \mathrm{GnRH-KLH.} \mathrm{Brief} \mathrm{anesthesia}$ was induced by administration of isoflurane (IsoFlo ${ }^{\circledR}$; Abbott Laboratories, North Chicago, IL, USA) by face mask. The hair from the right cranial thigh was clipped, and the injection site was cleaned with $70 \%$ isopropyl alcohol. The vaccine $(0.5 \mathrm{ml})$ was injected into the quadriceps muscle group. The right pinna was tattooed with a code indicating the treatment given. 
Potential adverse reactions to immunization were evaluated by daily physical examination, including inspection of the injection site and measurement of body temperature for 1 week following treatment. Body weights of the cats were recorded monthly.

\subsection{Detection of GnRH antibodies}

Blood $(3 \mathrm{ml})$ was collected by jugular venipuncture monthly into serum separator tubes. Serum was separated by centrifugation and stored at $-20{ }^{\circ} \mathrm{C}$ until assayed for GnRH antibodies by ELISA. Each 96-well plate was prepared by adding $100 \mathrm{ng}$ of BSAGnRH antigen to each well and blocking with PBS-2\% powdered milk. Since a KLHGnRH conjugate was used in the vaccine, BSA-GnRH was used to coat wells so that only antibody to GnRH would be detected. Cat serum was tested at four-fold dilutions to endpoint titers. Two negative controls were run on each plate; one negative control was buffer without cat serum and the other was pre-vaccination cat serum. High-titer cat serum was used as the positive control. Antibody to GnRH was detected by rabbit anti-cat IgG followed by goat anti-rabbit horse radish peroxidase (HRP) (Sigma Chemical Co., St. Louis, MO, USA). Color was developed by 3,3',5,5' tetramethylbenzidine (TMB) (Sigma Chemical Co.).

\subsection{Determination of serum testosterone concentration}

Blood was collected monthly for determination of testosterone concentration. Serum samples were analyzed for total testosterone by RIA (Coat-A-Count ${ }^{\circledR}$; Diagnostic Products Corporation, Los Angeles, CA, USA) according to the manufacturer's instructions. The manufacturer reports a sensitivity of $4 \mathrm{ng} / \mathrm{dl}$ with within-run coefficient of variation $(\mathrm{CV})$ of $4-18 \%$ and between-run $\mathrm{CV}$ of $6-11 \%$, depending on the testosterone concentration.

\subsection{Phenotypic responses}

Scrotal volume was determined prior to treatment and at monthly intervals thereafter. The height and width of each scrotal sac was measured with electronic calipers. The volume of each sac was calculated according to the formula [length $(\mathrm{cm}) \times$ width $(\mathrm{cm}) \times$ 0.524] [13], and the total volume was determined by adding the volumes of the left and right sacs together. Six months after treatment, the penis of each cat was examined for the presence of testosterone-dependent spines [14]. Following castration, the paired testicular weights of each cat were determined.

\subsection{Semen analysis}

Six months after treatment, cats were sedated by intramuscular injection of $35-45 \mathrm{mg}$ tiletamine-zolazepam $\left(\right.$ Telazol $^{\circledR}$; Fort Dodge Animal Health, Fort Dodge, IA, USA) for electroejaculation. A Teflon rectal probe $(1 \mathrm{~cm}$ in diameter $\times 13 \mathrm{~cm}$ in length) with three stainless steel electrodes $(2.6 \mathrm{~mm}$ in width and $3.75 \mathrm{~cm}$ in length) and an AC 60-Hz sine wave electroejaculator with a variable transformer were used to deliver the 
electrical stimuli (P.T. Electronics, Boring, OR, USA). The standardized ejaculation sequence was divided into three series of stimulations ranging from 2 to $5 \mathrm{~V}$ as described [13]. Ejaculates were immediately analyzed for volume, forward progressive motility, and sperm count. Forward progressive motility percentages were estimated by subjective microscopic examination at $200 \times$ magnification. Sperm concentration was determined using a commercial diluent (Unopette ${ }^{\circledR}$ microcollection system for RBC; Becton Dickinson and Co., Franklin Lakes, NJ, USA) and standard hemacytometer. A 10-ul aliquot of the ejaculate was fixed in $1 \%$ glutaraldehyde for morphological examination. Smears prepared from fixed sperm were stained with eosin B/ nigrosin and evaluated with conventional light microscopy $(200 \times)$. A total of 200 spermatozoa were examined for each sample and were classified as normal, abnormal head, abnormal midpiece, abnormal tail, and presence of proximal or distal cytoplasmic droplets [13].

\subsection{Pathologic evaluation of testes}

Following castration, testicular tissue samples were collected, embedded in paraffin, sectioned at $4 \mu \mathrm{m}$ and stained with haematoxylin and eosin (H\&E). Histological examination of the testicles was conducted by a veterinary pathologist blinded to the treatment groups (J.W.R.). The examination included assessment of the populations of interstitial (Leydig) cells, Sertoli cells, and the proliferation and maturation of spermatocytes/ spermatids. The average number of spermatids was obtained by counting the number of mature spermatids located in the lumen of the seminiferous tubules from 10 random high power fields (hpf).

\subsection{Statistical analysis}

Descriptive statistics (mean \pm S.E.) were calculated for each group. Normally distributed data compared over time (GnRH antibody titer, testosterone concentration, scrotal size) were evaluated using one-way repeated measures analysis of variance. The HolmSidak method pairwise multiple comparison procedure was used to identify the groups that differed from the others. Nonparametric data (semen analysis, testes histology) were evaluated using the Mann-Whitney rank sum test. The Spearman rank order correlation test was used to evaluate the correlation of GnRH antibody titer with serum testosterone concentration in data pooled from all time points. Differences were considered significant when $P<0.05$. All tests were performed using SigmaStat ${ }^{\circledR}$ statistics software (SPSS Inc., Chicago, IL, USA).

\section{Results}

\subsection{Reactions to treatment}

Following treatment, body temperature remained normal. No inflammation or tenderness at the injection site was detected in any of the cats. Cats gained weight 
throughout the study, and there was no difference in weight gain among treatment groups $(P=0.7)$.

\subsection{Detection of GnRH antibodies}

GnRH antibodies were detected in all cats receiving GnRH vaccine, but not in shamtreated cats, by 1 month post-treatment and persisted throughout the 6-month study. No dose effect of $\mathrm{GnRH}$ was observed as titers were not significantly different between cats treated with 50, 200, or $400 \mu \mathrm{g} \mathrm{GnRH}(P=0.5)$. A breakpoint in physiologic responses was observed at titers of 32,000. Therefore, cats were divided into three groups: sham, responders (antibody titer $>32,000$ ), and nonresponders (antibody titer $\leq 32,000$ ). Six of nine treated cats had a robust response to immunization characterized by GnRH antibody titers $>32,000$. Three of nine treated cats had poor responses to GnRH treatment with GnRH antibody titers of 4000-32,000 (Fig. 1).

\subsection{Serum testosterone concentrations}

Serum testosterone was undetectable in responder cats by 3 months post-treatment. There was no significant change in testosterone concentrations in sham-treated cats $(P>0.2)$ or nonresponder cats $(P=0.05)$ compared to baseline values, except at 4 months, when testosterone increased transiently in sham-treated cats $(P=0.01$; Fig. 2$)$.

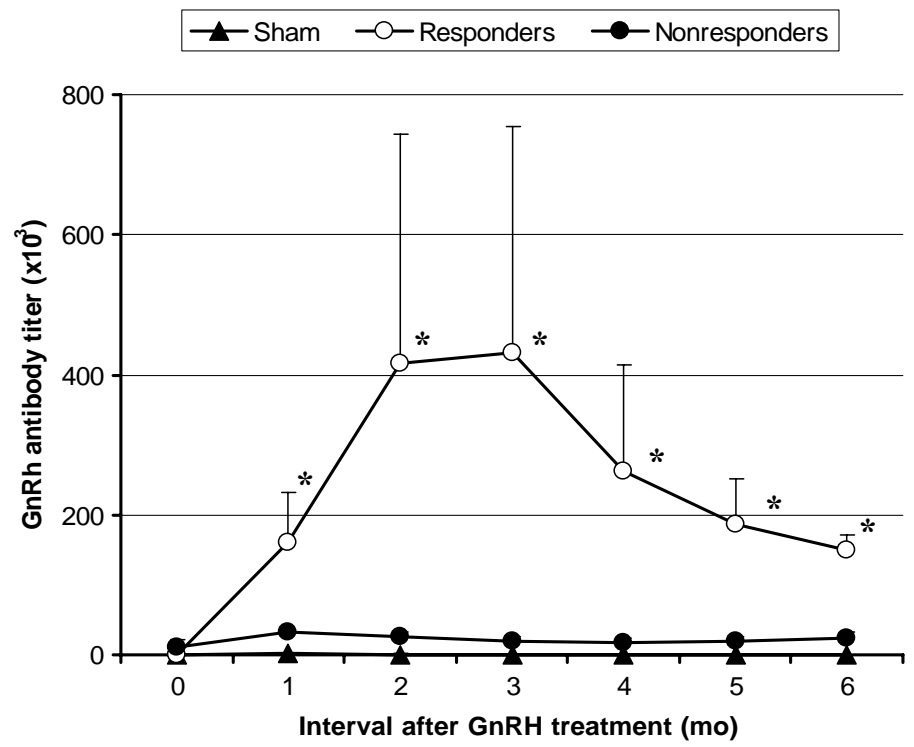

Fig. 1. GnRH antibody titer (mean \pm S.E.) following a single treatment with a GnRH immunocontraceptive vaccine $(n=9)$ or sham treatment $(n=3)$. Six treated cats were classified as responders (titer $>32,000)$ and three cats were nonresponders (titer 4000-32,000). Responders had significantly higher antibody titers than nonresponders from 1 to 6 months post-GnRH treatment $\left({ }^{*} P<0.05\right)$. 


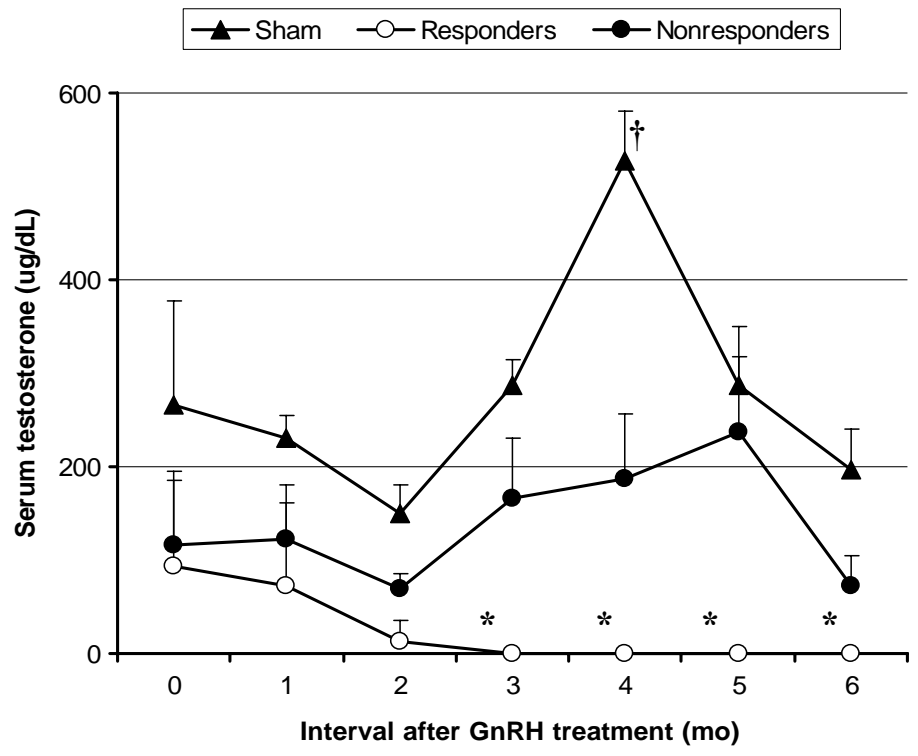

Fig. 2. Serum testosterone concentration (mean \pm S.E.) was significantly lower than pretreatment values in responder cats by 3 months post-GnRH treatment $\left({ }^{*} P<0.05\right)$. Testosterone concentrations did not change significantly in sham-treated $(P=0.2)$ and nonresponder cats $(P=0.05)$, except at 4 months when sham-treated cats has a transient increase in testosterone $\left({ }^{\dagger} P=0.01\right)$.

Serum testosterone concentration was negatively correlated with GnRH antibody titer $(r=-0.77 ; P<0.001)$.

\subsection{Phenotypic responses}

By 3 months post-treatment, testicular atrophy in cats responding to $\mathrm{GnRH}$ treatment was evidenced by a sustained reduction in scrotal volume $(P<0.001)$. Scrotal volume did not change over time in the sham-treated $(P=0.05)$ and nonresponder cats $(P=0.5$; Fig. 3) At 6 months post-treatment, testosterone-dependent penile spines were well-developed in sham-treated cats and nonresponder cats, but were absent from cats responding to GnRH treatment (Fig. 4). Combined testicular weights of responder cats averaged $1.3 \pm 0.1 \mathrm{~g}$ and were lower than sham-treated controls $(5.3 \pm 1.3 \mathrm{~g} ; P=0.02)$ and nonresponder cats $(2.9 \pm 0.3 \mathrm{~g} ; P=0.02)$. Testicular weights of sham-treated cats were not different from those of nonresponder cats $(P=0.2)$.

\subsection{Semen analysis}

At 6 months, the three sham-treated cats had excellent semen quality characterized by high sperm counts and progressive motility. Of the three nonresponder cats, two (2A, 4C) had lower sperm counts with reduced motility, and one (3B) had normal semen quality (Table 1). 


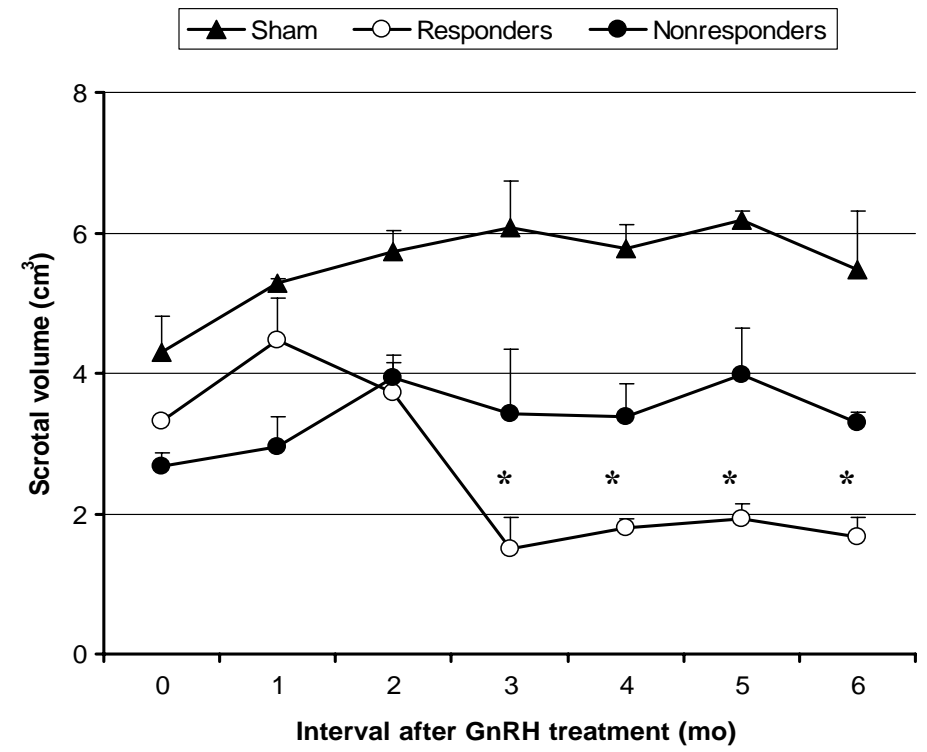

Fig. 3. Scrotal volume (mean \pm S.E.) was significantly lower than pretreatment values in responder cats by 3 months post-GnRH treatment $\left({ }^{*} P<0.001\right)$. Scrotal volume did not change in sham-treated cats $(P=0.05)$ and nonresponder cats $(P=0.5)$.

Overall, the sperm concentration for sham-treated cats $\left(70.3 \pm 26.8 \times 10^{6} \mathrm{sperm} / \mathrm{ml}\right)$ was similar to that for nonresponder cats $\left(39.4 \pm 19.4 \times 10^{6} \mathrm{sperm} / \mathrm{ml} ; P=0.7\right)$. Likewise, total sperm counts were similar for sham-treated cats $\left(3.1 \pm 1.8 \times 10^{6}\right.$ sperm $)$ and nonresponders cats $\left(3.4 \pm 1.6 \times 10^{6}\right.$ sperm; $\left.P=0.7\right)$. Only one $(2 \mathrm{C})$ of the six responder cats produced

Table 1

GnRH antibody titer, testosterone concentration, semen characteristics, and physical findings of cats 6 months after GnRH immunization

\begin{tabular}{llclllllll}
\hline Cat & $\begin{array}{l}\text { Treatment } \\
(\mu \mathrm{g} \mathrm{GnRH})\end{array}$ & $\begin{array}{l}\text { GnRH } \\
\text { antibody } \\
\text { titer }\left(10^{3}\right)\end{array}$ & $\begin{array}{l}\text { Serum } \\
\text { testosterone } \\
(\mu \mathrm{g} / \mathrm{dl})\end{array}$ & $\begin{array}{l}\text { Semen } \\
\text { volume } \\
(\mu \mathrm{l})\end{array}$ & $\begin{array}{l}\text { Sperm } \\
\text { concentration } \\
(\text { number/ml } \\
\left.\times 10^{6}\right)\end{array}$ & $\begin{array}{l}\text { Total } \\
\text { sperm } \\
\text { count } \\
\left(\times 10^{6}\right)\end{array}$ & $\begin{array}{l}\text { Sperm } \\
\text { motility }\end{array}$ & $\begin{array}{l}\text { Combined } \\
\text { testes } \\
\text { weight }(\mathrm{g})\end{array}$ & $\begin{array}{l}\text { Penile } \\
\text { spines }\end{array}$ \\
\hline 1A & Sham & 0 & 110 & 105 & 63 & 6.6 & 90 & 7.1 & + \\
1B & Sham & 0 & 240 & 50 & 28 & 1.4 & 85 & 3.0 & + \\
1C & Sham & 0 & 240 & 10 & 120 & 1.2 & 90 & 5.7 & + \\
2A & 50 & 32 & 100 & 115 & 1.1 & 1.3 & 5 & 3.0 & \pm \\
2B & 50 & 256 & 0 & 12 & 0 & 0 & No sperm 1.2 & - \\
2C & 50 & 128 & 0 & 15 & 0.01 & 0.0002 & 0 & 1.7 & - \\
3A & 200 & 128 & 0 & 15 & 0 & 0 & No sperm 1.3 & - \\
3B & 200 & 32 & 10 & 35 & 64 & 2.2 & 80 & 2.3 & + \\
3C & 200 & 128 & 0 & 10 & 0 & 0 & No sperm & 0.9 & - \\
4A & 400 & 128 & 0 & 13 & 0 & 0 & No sperm 1.5 & - \\
4B & 400 & 128 & 0 & 12 & 0 & 0 & No sperm 1.2 & - \\
4C & 400 & 8 & 110 & 125 & 53 & 6.6 & 25 & 3.3 & + \\
\hline
\end{tabular}



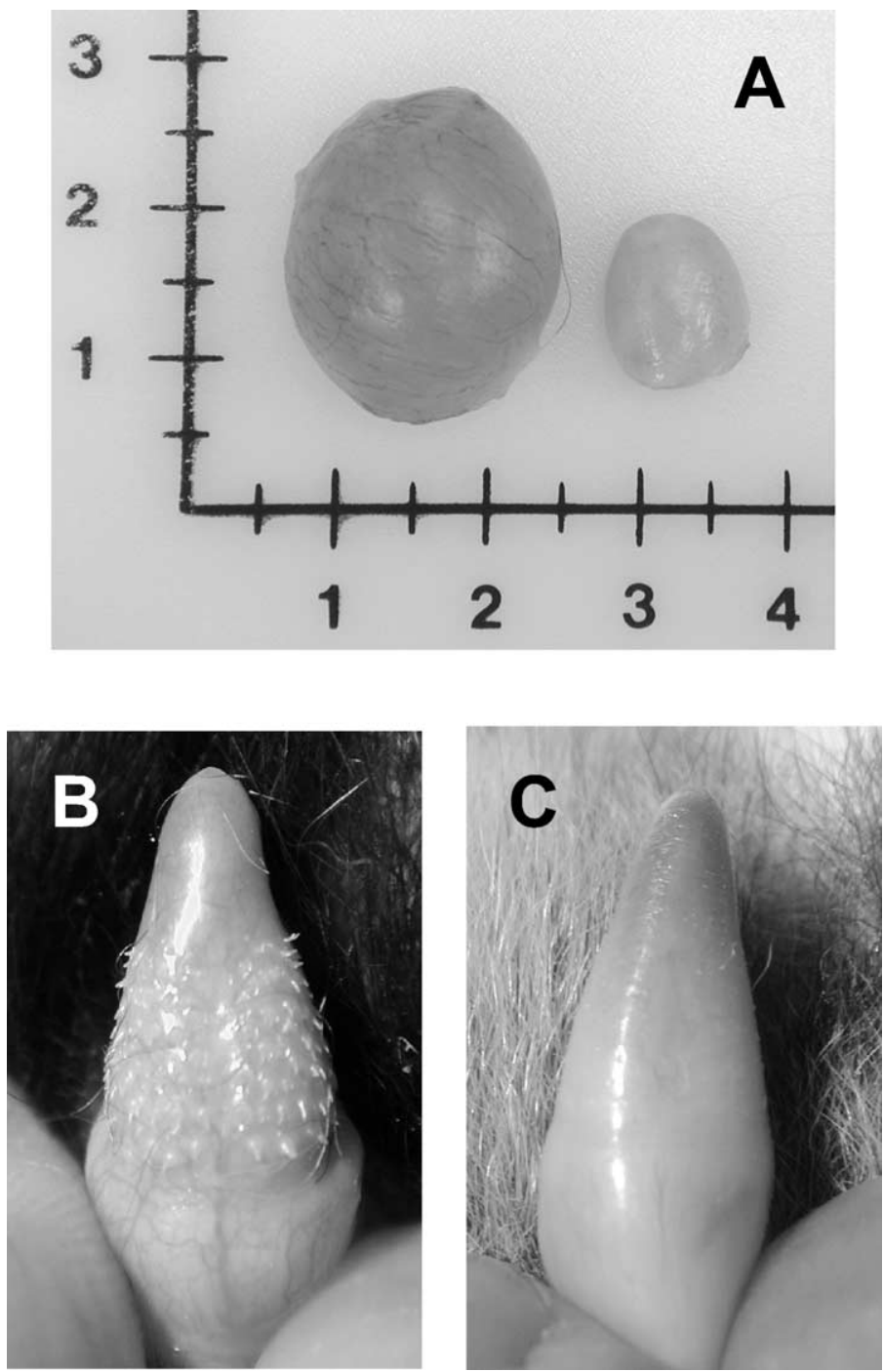

Fig. 4. Marked testicular atrophy (A) was present 6 months after GnRH treatment of cat 4B (right) compared to sham-treated cat $1 \mathrm{C}$ (left). Scale is in centimeters. Penile spines were well-developed in cat $1 \mathrm{C}$ (B) but were absent in cat $4 \mathrm{~B}(\mathrm{C})$.

sperm, none of which were motile. The sperm concentration $\left(0.01 \times 10^{6}\right.$ sperm $\left./ \mathrm{ml}\right)$ and total sperm count $\left(0.0002 \times 10^{6}\right)$ for cat $2 \mathrm{C}$ were very low compared to the sham-treated and nonresponders cats (Table 1). The percentage of sperm with normal morphology was similar in sham-treated cats $(58 \pm 12 \%)$ and the nonresponders cats $(65 \pm 12 \%)(P=0.7)$. The most common abnormalities in both groups were curved tail $(13 \pm 4 \%)$, bent midpiece $(11 \pm 9 \%)$. and bent tail $(13 \pm 8 \%)$. 

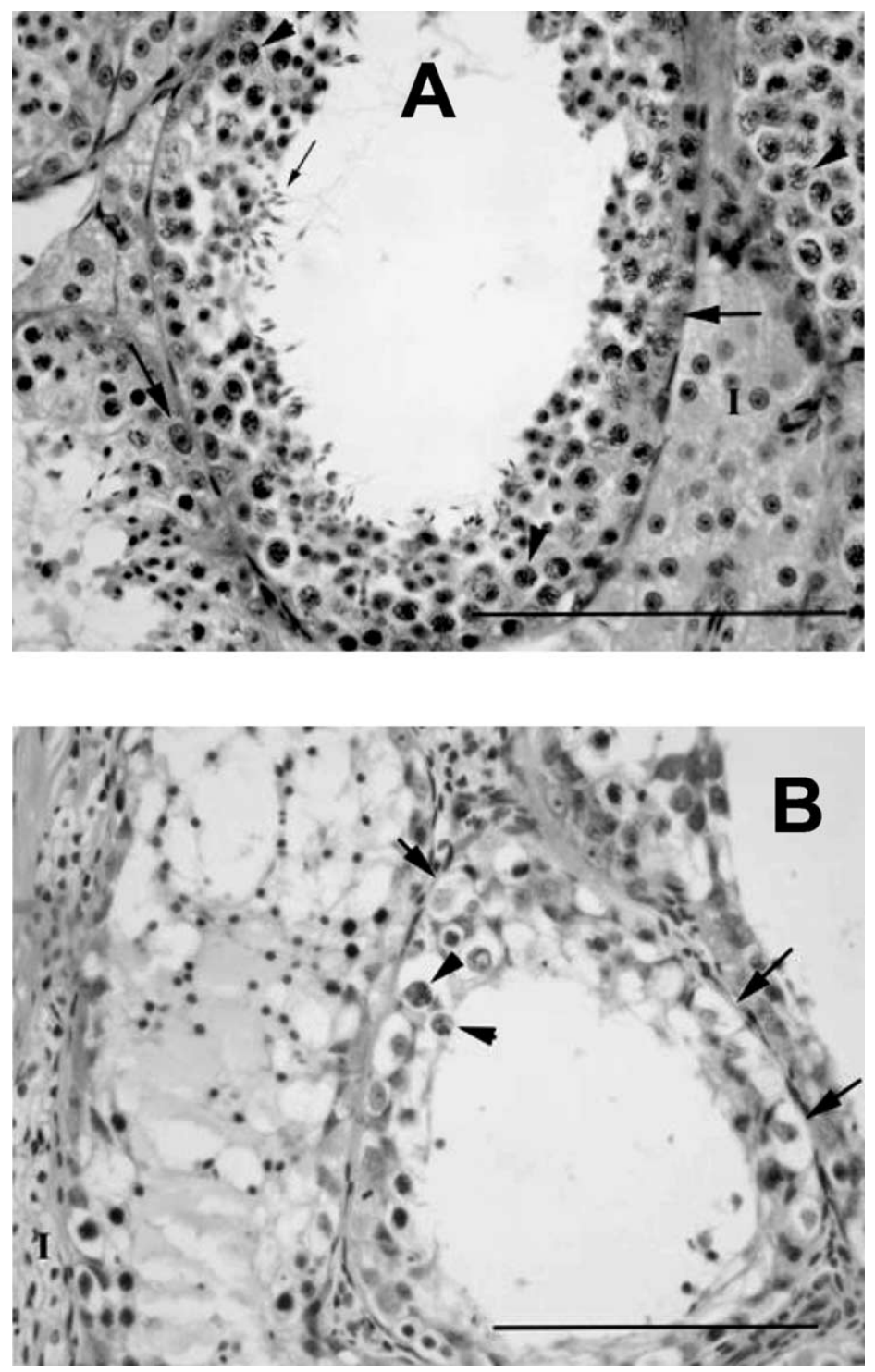

Fig. 5. Sham-treated control cats (A) exhibited large polyhedral interstitial cells expanding the interstitium (I). The seminiferous tubules contained Sertoli cells (large arrows) supporting numerous germ cells (arrowheads) with maturation evident to mature spermatids (small arrows). The most conspicuous cells present in the cats responding to GnRH treatment (B) were vacuolated Sertoli cells (arrows, see also Fig. 6). Germ cells were not easily identified in most regions and there were numerous scattered cells undergoing necrosis (arrowheads). Interstitial cells (I) were pale and shrunken. H\&E stain. Bar $=115 \mu \mathrm{m}$. 


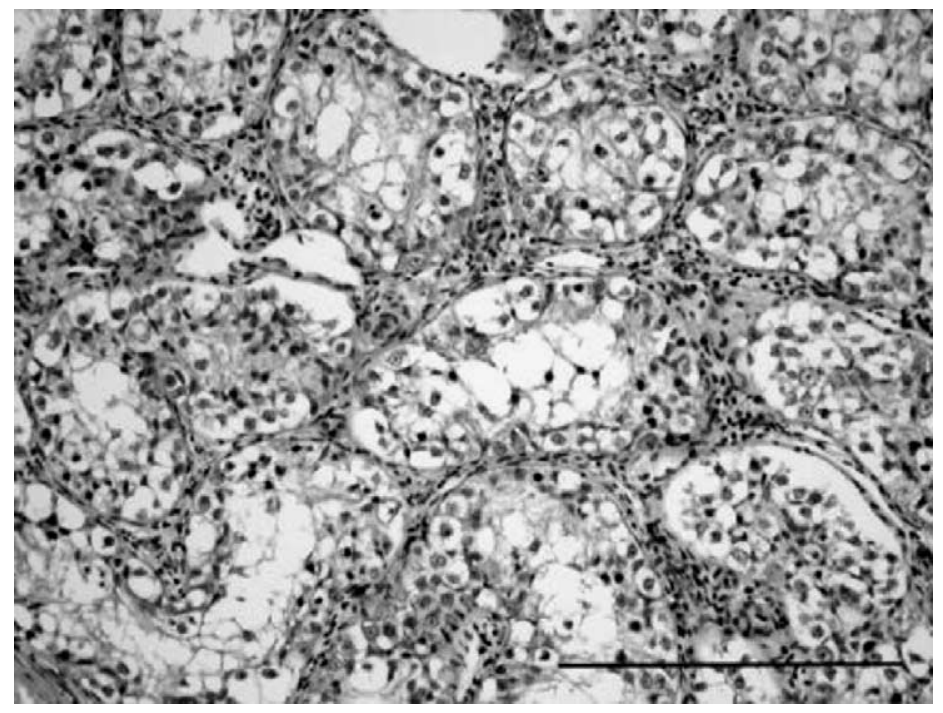

Fig. 6. Regionally, some of the responder cats had such extensive vacuolation of the Sertoli cells that the seminiferous tubular lumen was obscured. H\&E stain. Bar $=250 \mu \mathrm{m}$.

\subsection{Pathologic evaluation of testes}

Histologically, testicles from sham-treated cats exhibited a conspicuous population of interstitial (Leydig) cells (Fig. 5A). In contrast, testicles from cats that responded to GnRH treatment had marked interstitial cell atrophy (Fig. 5B). Morphologically, the interstitial cells that were present were pale and shrunken compared to the plump, polyhedral eosinophilic cells in sham-treated cats. Testicular seminiferous tubules from sham-treated cats were uniformly populated by Sertoli cells and germ cells, and displayed normal production and maturation of spermatids that were easily identified in tubular lumens (Fig. 5A). In contrast, GnRH responder cats had marked tubular atrophy with vacuolated Sertoli cells and a paucity of germ cells (Figs. 5B and 6). Even after examination of numerous microscopic fields, mature spermatids could be identified in only three of the six responder cats. The number of sperm/10 hpf in the responder cats $(1.8 \pm 0.4)$ was lower than the number in sham-treated cats $(437 \pm 209 ; P=0.02)$ and nonresponder cats $(521 \pm 169 ; P=0.02)$.

\section{Discussion}

In this study, 12 sexually intact adult male cats were immunized once with $0-400 \mu \mathrm{g}$ GnRH. No injection site or systemic reactions were noted during the 6-month observation period. As expected, the GnRH antibody titer was negatively correlated with serum testosterone concentration. At final evaluation 6 months post-injection, six of nine treated cats had GnRH antibody titers $>64,000$. These "responder" cats had undetectable serum 
testosterone, marked testicular atrophy, and absence of viable sperm in semen samples. Three of nine treated cats had a partial response to immunization with GnRH. These "nonresponders" had GnRH antibody titers of 4000-32,000 accompanied by intermediate serum testosterone concentrations, testicular atrophy, and semen quality. Although testosterone and/or semen quality in nonresponders was decreased, variable numbers of motile sperm were present in semen, indicating that fertility may not be completely suppressed in cats with low GnRH antibody titers. Breeding trials were not performed to confirm fertility in this pilot study.

The reason that some cats fail to produce high antibody titers against $\mathrm{GnRH}$ is unknown. It does not appear to be dose-related, since cats in each dose group produced both high and low titers. It is possible that in some cats the immune response was diverted to the carrier protein $(\mathrm{KLH})$, the mycobacterial adjuvant, or other vaccine components instead of GnRH. The relative immune responses to the various components of the vaccine are currently under investigation.

Immunocontraception was not achieved in a previous study [15] in which male cats were treated three or four times with synthetic GnRH conjugated with tetanus toxoid and adjuvanted with $\mathrm{N}$-acetyl-nor-muramyl-L-alanyl-D-isoglutamine. GnRH antibody titers were similar to those detected in dogs that responded transiently to the same treatment, but serum testosterone concentrations did not decrease in cats [15]. In another study, 4 male and 10 female kittens were immunized with GnRH at 8 and 12 months and approximately 2 years of age. Serum testosterone concentrations were suppressed in three of four males for the duration of the study. Reproductive activity was not observed in the females, but hormone concentrations were not reported [16]. In another study in which LH receptors (LHR) were targeted lower in the endocrine cascade, bovine LHR combined with $\mathrm{N}$ acetylglucosaminyl-( $\beta 1-4) \mathrm{N}$-acetylmuramyl-L-alanyl-D-isoglutamine adjuvant was administered in silastic implants placed under the skin of female cats [17]. These implants were followed by a series of four boosters administered intramuscularly to maintain LHR antibody titers. The appearance of LHR antibodies was associated with decreased serum progesterone concentrations and cessation of estrus cycling, but estrogen concentrations were not affected. Recovery of estrus cycling occurred when antibody titers decreased after1 year. Although the LHR study provided proof of principal that blockade of the hypothalamic-pituitary-gonadal axis by immunocontraceptive vaccination may be effective in cats, the effect required multiple treatments and was relatively short-lived, making such treatment impractical for use in free-roaming cats [17].

Most reports of GnRH immunocontraception outside of laboratory species have involved juvenile food-producing species as an alternative to surgical gonadectomy of animals intended for slaughter. In this situation, sterilization is performed to prevent undesirable effects of sex hormones on estrus cycling, aggressive behavior, and androgen-related taint, which reduce feed efficiency and carcass quality. In most reports, a series of prime-boost treatments was given and the follow-up period was short. GnRH immunization resulted in decreased testosterone, $\mathrm{LH}$, and progesterone concentrations, testes size, estrus cycling, libido, aggression, and androgen-related taint in calves [18-22], piglets [23-27], and lambs [28-30]. Similar responses were observed in adult stallions [31] and cows [32].

GnRH immunocontraception has also been investigated for controlling "pest species" of wildlife, which present many of the same challenges encountered in control programs 
for free-roaming feral cats. In adult female white tail deer given multiple treatments, estrus cycling and progesterone were suppressed $[9,10]$. In some cases, does that did conceive aborted their fetuses due to inadequate ovarian production of progesterone. Overall fawning rates were markedly reduced compared to untreated control does. Male deer treated with $\mathrm{GnRH}$ had decreased testosterone concentrations and testes size and poor libido [9]. Antlers of male deer remained in velvet and were dropped earlier than in control bucks. A single GnRH immunization was $100 \%$ effective in both female and male Norway rats [11]. Immunity lasted $>1$ year in most rats, which may equate to the reproductive lifespan of rats living in the wild. GnRH treatment resulted in high antibody titers in a variety of other wildlife species requiring population control, including squirrels, rabbits, coyotes, horses, bison, and pigs [12].

Promising results in multiple species suggest that $\mathrm{GnRH}$ immunocontraception may represent a broad tool for population control of wildlife. However, in almost every report, a series of treatments was required for adequate immunity and a portion of animals failed to respond to treatment and remained fertile. Universally, physiologic responses were correlated with GnRH antibody titer. Animals with high titers were sterile, whereas those animals with lower titers were not. GnRH immunocontraception appears to be reversible when antibody titers wane over time. While this may be desirable in the management of some species, an ideal cat contraceptive would provide permanent sterilization. Widespread use of immunocontraceptive vaccines for free-roaming cats in the field will require the development of products that provide long-term immunity with a single treatment in a high proportion of animals.

The results presented in this report suggest that GnRH may be an effective immunocontraceptive antigen for cats. GnRH is an ideal target, because, in addition to contraception, the effect of its neutralization is to block the production of sex hormones such as estrogen and testosterone, which contribute to objectionable behavior and medical diseases in cats. A longer duration study in a larger number of cats of both sexes is necessary to determine duration of immunity and true rate of efficacy of $\mathrm{GnRH}$ immunocontraception in cats.

\section{Acknowledgements}

Supported by NIH RR-00124. The authors acknowledge technical assistance by Holly Jordan, Kristin MacDonald, Karen Scott, and Marc Salute and excellent animal care by Alex Trapp and Deborah Malcolm.

\section{References}

[1] Kuehn BM, Kahler SC. The cat debate. J Am Vet Med Assoc 2004;224:169-73.

[2] Grandy JW, Rutberg AT. An animal welfare view of wildlife contraception. Reprod Suppl 2002;60:1-7.

[3] Murdoch WJ. Immunoregulation of mammalian fertility. Life Sci 1994;55:1871-86.

[4] Miller LA, Johns BE, Elias DJ. Immunocontraception as a wildlife management tool: some perspectives. Wildl Soc Bull 1998;26:237-43.

[5] Thompson DL. Immunization against GnRH in male species (comparative aspects). Anim Reprod Sci 2000;60/61:459-69. 
[6] Belda M, Covenas R, Naraez JA, Aguirre JA, Tramu G. Distribution of luteinizing hormone-releasing hormone in the upper brainstem and diencephalons of the cat: an immunocytochemical study. Brain Res Bull 2000;51:281-91.

[7] Bakker J, Baum MJ. Neuroendocrine regulation of GnRH release in induced ovulators. Front Neuroendocrinol 2000;21:220-62.

[8] Talwar GP. Immunobiology of gonadotropin-releasing hormone. J Steroid Biochem 1985;23:795-800.

[9] Miller LA, Johns BE, Killian GJ. Immunocontraception of white-tailed deer with GnRH vaccine. Am J Reprod Immunol 2000;44:266-74.

[10] Curtis PD, Pooler RL, Richmond ME, Miller LA, Mattfeld GF, Quimby FW. Comparative effects of GnRH and porcine zona pellucida (PZP) immunocontraceptive vaccines for controlling reproduction in white-tailed deed (Odocoileus virginianus). Reprod Suppl 2002;60:131-41.

[11] Miller LA, Johns BE, Elias DJ, Crane KA. Comparative efficacy of two immunocontraceptive vaccines. Vaccine 1997;15:1858-62.

[12] Fagerstone KA, Miller LA. GnRH immunocontraception: a possible control for populations of feral cats. In: Proc Int Symp Nonsurgical Methods for Pet Population Control, 2002; Pine Mountain, GA, p. 48-50 [abstract].

[13] Howard JG, Brown JL, Bush M, Wildt DE. Teratospermic and normospermic domestic cats: ejaculate traits, pituitary-gonadal hormones, and improvement of spermatozoal motility and morphology after swim-up processing. J Androl 1990;11:204-15.

[14] Aronson LR, Cooper ML. Penile spines of the domestic cat: their endocrine-behavior relations. Anat Rec 1967;157:71-8.

[15] Ladd A, Tsong YY, Walfield AM, Thau R. Development of an antifertility vaccine for pets based on active immunization against luteinizing hormone-releasing hormone. Biol Reprod 1994;51:1076-83.

[16] Robbins SC. Active immunization of prepubertal cats against gonadotropin releasing hormone and its effects on gonadal hormonal concentration and reproductive function. In: Proc Int Symp Nonsurgical Methods for Pet Population Control, 2002; Pine Mountain, GA, p. 51-3 [abstract].

[17] Saxena BB, Clavio A, Singh M, Rathnam P, Bukharovich EY, Reimers Jr TJ, et al. Effect of immunization with bovine luteinizing hormone receptor on ovarian function in cats. Am J Vet Res 2003;64:292-8.

[18] Huxsoll CC, Price EO, Adams TE. Testis function, carcass traits, and aggressive behavior of beef bulls actively immunized against gonadotropin-releasing hormone. J Anim Sci 1998;1760-6.

[19] Finnerty M, Enright WJ, Roche JF. Testosterone, LH and FSH episodic secretory patterns in GnRHimmunized bulls. J Reprod Fertil 1998;114:85-94.

[20] Cook RB, Popp JD, Kastelic JP, Robbins S, Harland R. The effects of active immunization against GnRH on testicular development, feedlot performance, and carcass characteristics of beef bull. J Anim Sci 2000;78:2778-83.

[21] Adams TE, Daley CA, Adams BM, Sakurai H. Testes function and feedlot performance of bulls actively immunized against gonadotropin-releasing hormone: effect of age at immunization. J Anim Sci 1996;74:950-4.

[22] Jago JG, Cox NR, Bass JJ, Matthews LR. The effect of prepubertal immunization against gonadotropinreleasing hormone on the development of sexual and social behavior of bulls. J Anim Sci 1997;75: 2609-19.

[23] Dunshea FR, Colantoni C, Howard K, McCauley I, Jackson P, Long KA, et al. Vaccination of boars with a GnRH vaccine (Improvac) eliminates boar taint and increases growth performance. J Anim Sci 2001;79:2524-35.

[24] Zeng XY, Turkstra JA, Tsigos A, Meloen RH, Liu XY, Chen FQ. Effects of active immunization against $\mathrm{GnRH}$ on serum LH, inhibin A, sexual development and growth rate in Chinese female pigs. Theriogenology 2002;58:1315-26.

[25] Zeng XY, Turkstra JA, Meloen RH, Liu XY, Chen FQ, Schaaper WMM, et al. Active immunization against gonadotrophin-releasing hormone I Chinese male pigs: effects of dose on antibody titer. Theriogenology 2002;70:223-33.

[26] Meloen RH, Turkstra JA, Lankhof H, Puijk WC, Schaaper WM, Dijkstra G, et al. Efficient immunocastration of male piglets by immunoneutralization of $\mathrm{GnRH}$ using a new GnRH-like peptide. Vaccine 1994;12:741-6. 
[27] Bonneau M, Dufour R, Chouvet C, Roulet C, Meadus W, Squires EJ. The effects of immunization against luteinizing hormone-releasing hormone on performance, sexual development, and levels of boar taintrelated compounds in intact male pigs. J Anim Sci 1994;72:14-20.

[28] Kiyma Z, Adams TE, Hess BW, Riley ML, Murdoch WJ, Moss GE. Gonadal function, sexual behavior, feedlot performance, and carcass traits of ram lambs actively immunized against GnRH. J Anim Sci 2000;78:2237-43.

[29] Brown BW, Mattner PE, Carroll PA, Hoskinson RM, Rigby RD. Immunization of sheep against GnRH early in life: effects on reproductive function and hormones in ewes. J Reprod Fertil 1995;103:131-5.

[30] Brown BW, Mattner PE, Carroll PA, Holland EJ, Paull DR, Hoskinson RM, et al. Immunization of sheep against GnRH early in life: effects on reproductive function and hormones in rams. J Reprod Fertil 1994;101:15-21.

[31] Malmgren L, Andresen O, Dalin AM. Effect of GnRH immunisation on hormonal levels, sexual behaviour, semen quality and testicular morphology in mature stallions. Eq Vet J 2001;33:75-83.

[32] Cook RB, Popp JD, McAllister TA, Kastelic JP, Harland R. Effects of immunization against GnRH, melengestrol acetate, and a trenbolene acetate/estradiol implant on growth and carcass characteristics of beef heifers. Theriogenology 2001;55:973-81. 